\title{
LEACHATE DYNAMICS FROM MUNICIPAL JERUBAICIAI LANDFILL: MANAGEMENT AND CLARIFICATION
}

\author{
Vilda GRYBAUSKIEN $\dot{E}^{1}$, Gitana VYCIENE $\dot{E}^{2}$, A. GRUBAS ${ }^{3}$
}

\begin{abstract}
Leachate Dynamics from Municipal Jerubaiciai Landfill: Management and Clarification. Landfilling is currently a primary method for solid waste disposal. The proximity of many of these landfills to metropolitan water supplies, the frequency of landfill leachate contamination of groundwater sources, and the knowledge that leachate from landfills may be an important source of ground water pollution and urgent environmental problem. This paper describes leachate formation mechanism, summarizes leachate quality indicators. The aim of this article is to analyse Jerubaiciai landfill leachate management and dynamics of process and influence of main factors causing this problem. The reference periods cover all seasons. Leachate generation rates were monitored from 01/01/2016 to 31/12/2016, landfill receives more than 1050 tons of waste per weak. Chemical analysis was performed on the samples automatically as several parameters as $\mathrm{pH}$, electric conductivity, temperature, pressure. The study found that during the year the amount of leachate from a landfill was $\sim 6500 \mathrm{~m}^{3}$ per day. Investigation shows that the leachate electric conductivity content ranges from 590 - $1970 \mu \mathrm{S} / \mathrm{cm}$. The weather temperature ranged from $13.6^{\circ} \mathrm{C}$ (early winter period) $-23.5^{\circ} \mathrm{C}$ (late summer period). It was concluded that when the amount of leachate temperature increases, the amount of leachate electric conductivity content also increases.
\end{abstract}

Keywords: landfill leachate, water pollution, leachate electric conductivity

\section{INTRODUCTION}

Human activities are inevitably associated with the generation of waste (Frank, 2002). The more urbanized the society is, the larger volumes of waste are generated and more problems are associated with their management (Williams, 2005). Landfilling is currently a primary method for solid waste disposal (Cureton et al., 1991). The proximity of many of these landfills to metropolitan water supplies, the frequency of landfill leachate contamination of groundwater sources, and the knowledge that leachate from landfills may be an important source of ground water pollution and urgent environmental problem - all these factors have created a need for further understanding of the fate and persistence of the constant organic pollutants in the landfill leachate (Amokrane et al., 1997; Tatsi et al., 2003).

Leachate is formed when refuse moisture content exceeds its field capacity, which is defined as the maximum moisture that is retained in a porous medium

\footnotetext{
1 Aleksandras Stulginskis University, Universiteto st. 10, LT-53361 Kaunas, Lithuania. E-mail: vil-
} da.grybauskiene@asu.lt.gitana.vyciene@asu.lt, arvydasgr@plungeslaguna.lt 
without producing downward percolation. Many factors influence this process: snowmelt, precipitation, ground water, irrigation-recirculating (El-Fadel et al., 2002).

Leachate from municipal landfills contains a complex variety of organic and inorganic compounds (Baig et al., 1999). Composition of leachate depends on the age of the landfill, the degree of solid waste stabilization, solid waste characteristics and composition of waste, size of the hill and landfill geometry (Barber and Maris, 1984).

Several studies have been conducted on the treatment of landfill leachates with RO (Reverse Osmosis) processes. Chian and De Walle (1977) found RO membranes could be used to remove $>91 \%$ of tocsins from sanitary landfill leachate. McArdle et al. (1987) indicated that RO membranes could be used as a treatment technology for leachate from hazardous waste land disposal facilities.

The aim of this article is to analyze Jerubaiciu landfill leachate generated content and dynamics of the factors causing this problem.

\section{METHODOLOGY}

The leachate sampling was performed in a landfill leachate storage reservoir of municipal solid waste landfill in Plunge district. The landfill is 0.8 kilometers away from Plunge-Medingenai road. The waste which is gathered by the leachate-drain systems collected underneath the pile of waste. The leachate gathered later gets into the storage reservoir. From here it is often pumped up into the leachate cleaning equipment.

The cleaning of the leachate happens in RO after which forms the condensate and water. The condensate formed is returned to the top of the pile of waste, and the already clear leachate, like water, is let out to the bio storage reservoirs, from which later gets into the nearby canal. Throughout the year, $6500 \mathrm{~m}^{3}$ leachate is formed at the Jerubaiciai landfill.

The leachate from the leachate storage reservoir is served in the ring whirl in which when a certain amount of $\mathrm{HCl}$ is added, the filtrate reaches the necessary $\mathrm{pH}$ 6.5. The leachate is mixed and circulated by the vacuums in leachate storage reservoir, until it reaches the necessary $\mathrm{pH}$ level. From the ring whirl the leachate is sent through a re-filtering system, which consists of sand and special cassette filters.

The reverse osmosis principle applies is applied in all of leachate's processing equipment stages. If half conductive membrane, which transmits through only a certain size particles, divides two sodium solutions or contaminated liquids, the concentration then equalizes. In the RO modules, the process takes part when the filtrate moves through the membrane's surface. Unclean leachate's concentration slowly increases when the water runs through the module. The waste is filtered through and is left behind the membrane. So, the so called "concentrate" is taken out. The strained clean water flows into the water reservoir. 


\section{RESULTS AND DISCUSSIONS}

The analysis of the dynamics of the environmental data. When establishing the effect of the meteorological conditions to the leachate, it is necessary to study their dynamics during that period. The data is received from the meteorological stations' database. The average weather temperatures and amount of precipitation are shown in Fig. 1.

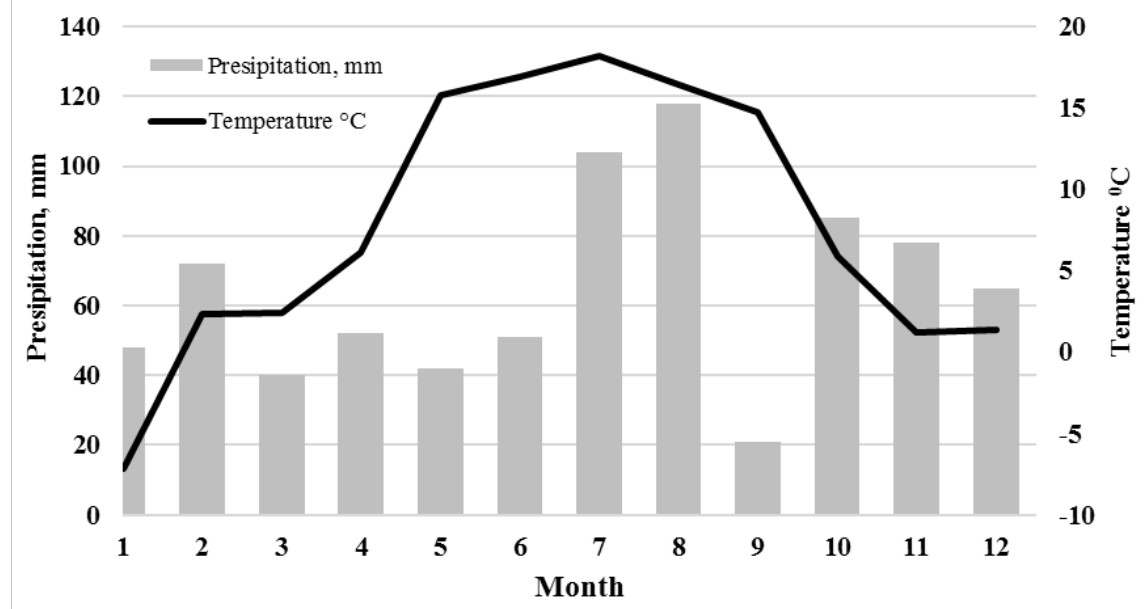

Fig. 1. The dynamics of precipitation and average air temperature per year 2016

During warm period from May to September of the year 2016, the average of temperature varied above $-15^{\circ} \mathrm{C}$. During winter, the temperatures were below $+1^{\circ} \mathrm{C}$, just in first month of the year the temperature was below $-7^{\circ} \mathrm{C}$. The average of year temperature is $+7.8^{\circ} \mathrm{C}$, long term weather temperature investigation results showed that this year was by $-1.1^{\circ} \mathrm{C}$ warmer.

Our investigation shows the same results. Linear dependency between the average air temperature throughout the air and the extracted leachate were found out. Correlation coefficient is $r=0,762$. It shows that air temperature strongly affects the amount of extracted leachate.

In the landfill, the leachate forms when the precipitation and water from the melting snow filtrates through the waste. Leachate is one of the main environmental problems associated with the clearing of the landfill because it has toxins such as organic materials, heavy metals and mineral oils which could harm water quality both underground and on the surface (Amokrane et al., 1997). The evaluation of precipitations dynamics shows that in July $-104 \mathrm{~mm}$, and in August - 118 $\mathrm{mm}$ fell, this is respectively - $26 \mathrm{~mm}$ and - $46 \mathrm{~mm}$ over long term norm. September was very dry, just - $21 \mathrm{~mm}$ (- $47 \mathrm{~mm}$ lower than norm) of precipitation. Lithuania is situated under excess soil moisture conditions - $695 \mathrm{~mm}$ precipitation/year and 
just $560 \mathrm{~mm} /$ year evapotranspiration, at period of our investigation there was $81 \mathrm{~mm}$ precipitation more than norm.

Per the schedule of the amount of precipitation, the changeable dynamics of precipitation is being fixed. During warm periods, most precipitation falls between the months of July and August -104-118 mm, and least - only $42 \mathrm{~mm}$ in April. In October, there can also be seen clear increase in precipitation $-85 \mathrm{~mm} 0$, but just $-21 \mathrm{~mm}$ in September. When analyzing data from 2016 (Fig. 2.), most precipitation fell during the months of June and July. There is around $60^{\circ} \mathrm{C}$ temperature 3 meters deep underground independently from the season of the year in landfill. It allows us to come up to a conclusion that precipitation in the summer evaporates and therefore the amounts of leachate are lower.

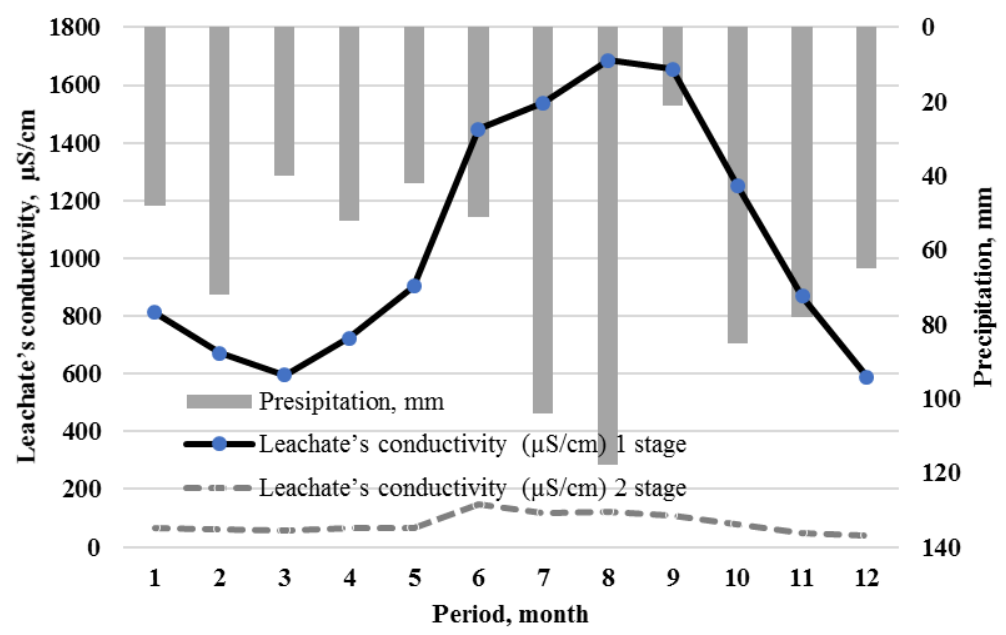

Fig. 2. The dynamics of the leachate conductivity in 1 and 2 stage of cleaning and dynamics of precipitation

The analysis of leachate cleaning measuring instrument's data. The landfill serves Telsiai county citizens and factories which have decreased their production levels. Such dynamics of the amount of waste influences the number of particles dissolved in the leachate which is registered by the distinct electrical measuring instrument.

Leachate's conductivity is not steady (Fig. 3.). Measurements were started in the beginning of the year and at that time the measuring instrument showed around $741 \mu \mathrm{S} / \mathrm{cm}$. Much higher meanings are registered during the summer months. The biggest registered meanings for long period from June 03 till October 05 , were no less than $1400 \mu \mathrm{S} / \mathrm{cm}$. High increase in leachate electric conductivity may have been caused by the constant high temperatures and low level of precipitation. During the existing high temperatures, the reactions in the pile of waste become more active. 


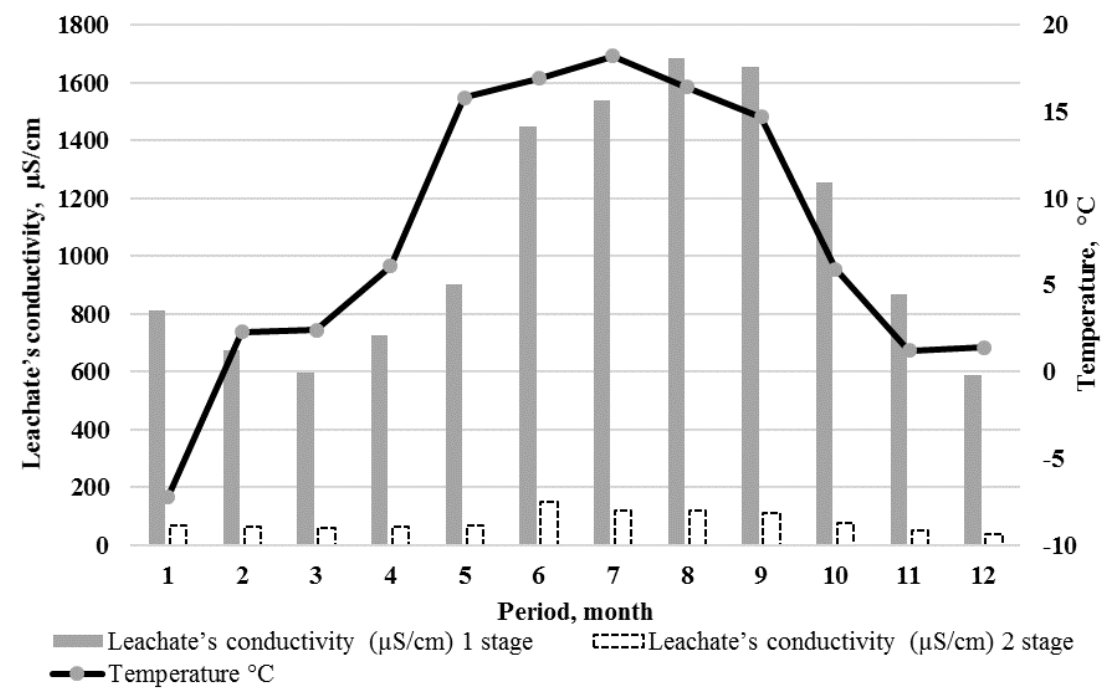

Fig. 3. The dynamics of the leachate conductivity in 1 and 2 stage of cleaning and dynamics of temperature

During the research, it was determined that when the summer season ends and temperatures drop, the number of dissolved particles decreases. When noticing even the smallest change in temperature, the leachate is also seen as changing. Figure 3 shows that leachate conductivity (stage 2) varied from $38 \mu \mathrm{S} / \mathrm{cm}$ in December up to $119 \mu \mathrm{S} / \mathrm{cm}$ in Jully. Investigations show that $10-360 \mu \mathrm{S} / \mathrm{cm}$ can be found in Lithuanian open ponds and rivers (Kilkus, 2002)

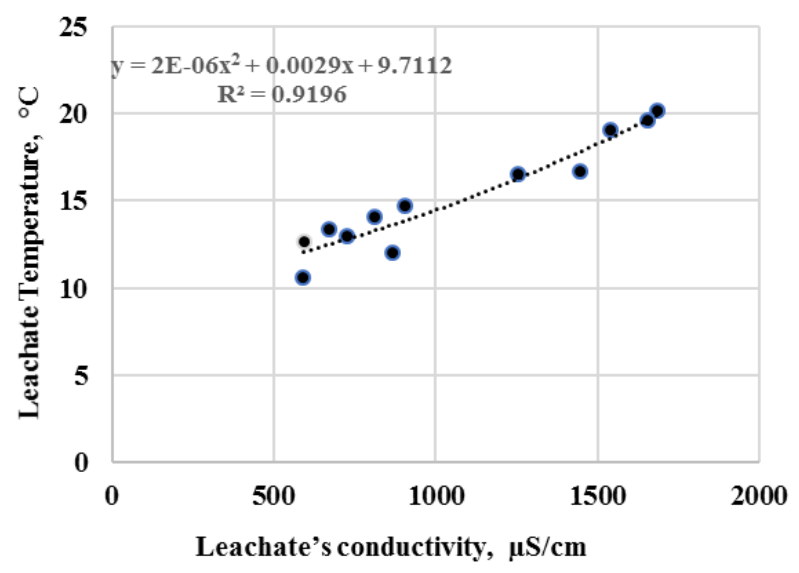

Fig. 4. Relationship between leachate conductivity and leachate temperature dynamics

After statistical analysis, we found out that there is very strong dependency between leachate conductivity and its temperature. We fixed the same dependency 
between weather temperature and leachate conductivity $\mathrm{r}=0,784$ in previous research (Grybauskiene and Vyciene 2013).

After analyzing stage 2 results, we found out that in May, it is around 90$100 \mu \mathrm{S} / \mathrm{cm}$ and stays as such until the summer. From the earlier discussed graph, we already know that in summer during the increase in temperature the leachate got into our previously discussed leachate cleaning installations in which the number of dissolved particles was higher. When we're observing already cleaned leachate we found out, that the contamination level is increasing, and the biggest meaning is noticed on July 27, and that is $160 \mu \mathrm{S} / \mathrm{cm}$. The average of leachate 1 electric conductivity in summertime is registered at around $110-140 \mu \mathrm{S} / \mathrm{cm}$. The amount of dissolved materials decreases only when the fall comes. We also registered that throughout almost entire fall the changes stay still, at 70-90 $\mu \mathrm{S} / \mathrm{cm}$. The only increase is registered in the middle of October. The already cleaned leachate (after 2 stage) data schedule seems to follow the schedule of the cleaning of leachate after 1 stage (fig. 3-4). From this we can conclude that there is a direct dependency between both data.

When analyzing the differences of the cleaned and not cleaned leachate's conductivity it was determined that when there is a higher amount of dissolved materials in the leachate, the cleaned leachate is also cleaned more effectively. Such effect could have been influenced by the changes in temperature. When there is a higher level of contamination of leachate, which is affected by the higher temperatures, the efficiency of the filtration increases. When processing the data statistically, we determined that the average meaning of the electric conductivity of leachate before cleaning is $725 \mu \mathrm{S} / \mathrm{cm}$, standard error -154 , after the cleaning the average meaning $-112 \mu \mathrm{S} / \mathrm{cm}$, standard error $-19,5$.

\section{CONCLUSIONS}

Meteorological conditions affect the dynamics of the leachate in landfills. During the day's higher average temperatures, the amount of leachate decreases, and during lower temperatures - increases.

A strong correlated dependency has been determined between air temperature and the amount of leachate electric conductivity extracted.

During research, most levels of precipitation have been registered in the months of June-July, but there was no increase in the amount of leachate. Precipitation from the summer evaporates from the pile of waste and does not get into the system of leachate gathering.

The filtrate is cleaned better when filtrate's electric conductivity is bigger and when the average air temperatures are higher. A strong correlated dependency has been determined between air temperature and the amount of leachate extracted $\mathrm{R}=0,916$.

After processing the data statistically, it was determined that the average meaning of the electric conductivity of leachate before cleaning was $725 \mu \mathrm{S} / \mathrm{cm}$, standard error -154 , after the cleaning the average meaning - $112 \mu \mathrm{S} / \mathrm{cm}$, standard error - 19,5. 


\section{REFERENCES}

1. Amokrane, A., Comel, C., Veron, J. (1997), Landfill leachate pretreatment by coagulation-flocculation. Water Research 31 (11), 2775.

2. Baig, S., Coulomb, I., Courant, P., Liechti, P. (1999), Treatment of landfill leachates: lapeyrouse and satrod case studies. Ozone Science and Engineering 21 (1), 122.

3. Barber, C., Maris, P. J. (1984), Recirculation of Leachate as A Landfill Management Option: Benefits and Operational Problems. Quarterly Journal of Engineering Chemosphere 53, 737-744.

4. Chian, E., De Walle, F. (1977), Evaluation of Leachate Treatment: Volume II, Biological and Physical-Chemical Processes. EPA Report, EPA-600/2-77-186b.

5. Cureton, P.M., Groenevelt, P.H., McBride, R.A. (1991), Landfill Leachate Recirculation: Effects on Vegetation Vigor and Clay Surface Cover Infiltration. Journal of Environmental Quality 20, 17-24.

6. El-Fadel, Bou-zed, M. E., Chanine, W., Alayli, B. (2002), Temproral variation of leachate quality from pre-sorted and baled municipal solid waste with high organic and moisture content. European scientific journal WOL. (3), 369-376.

7. Frank, K. (2002), Handbook of solid waste management. McGraw-Hill, New York.

8. Grybauskiene, M., Vyciene, G. (2013), Meteoritical and Human factors influence to leachate dynamics. Waste management 22 (3), 269-282.

9. Kilkus, K. (2002), Winter stratification in relation to lake morphometry and water conductance. Limnological Rewiew 2, 191-200.

10. McArdle, J., Arozarena, M., Gallagher, W. (1987), A Handbook on Treatment of Hazardous Waste Leachate. EPA Report, EPA/600/8-87/006.

11. Tatsi, A.A., Zouboulis, A.I., Matis, K.A., Samaras, P. (2003), Coagulationflocculation pretreatment of sanitary landfill leachates. Geology 17 (1), 19-29.

12. Williams, T. (2005), Waste treatment and disposal. Second edition. John Wiley and sons, LTd. England. 